\title{
Kontribusi Pemikiran Jihad Ekonomi Kiai Madura dalam Pengembangan Ekonomi Berbasis Syari'ah
}

\author{
Zainal Abidin \\ (STAIN Pamekasan, Jl. Panglegur KM. 04 Pamekasan, email: \\ zainal.madura@gmail.com) \\ Abdul Wahed \\ (STAIN Pamekasan, Jl. Panglegur KM. 04 Pamekasan, email: \\ awahed6@gmail.com )
}

\begin{abstract}
Abstrak:
Artikel ini mengkaji bagaimana sebenarnya nilai-nilai islam dapat dituangkan dalam dinamika bisnis yang dikembangkan oleh para kiai sebagai tokoh pengawal agama (Islam). penulis mencoba menganalisis peran kiai madura dalam pengembangan ekonomi berbasis syari'ah (hukum Islam), Islam sebagai agama juga dapat memiliki nilai-nilai atau spirit khas dalam upaya mengembangkan ekonomi umat. Disinilah urgensi peran para kiai madura -sebagai pengawal tegaknya nilai-nilai Islam dalam segala sektor, termasuk sektor di ekonomi dan bisnis. Nilai-nilai spiritual dari aktivitas bisnis yang dilakukan oleh para kiai madura dapat dipandang sebagai sebuah bentuk jihad di bidang ekonomi, yakni tegaknya nilai syari'ah (hukum islam) dalam bingkai ekonomi dan bisnis yang ditekuni dan kembangkan bersama masyarakat.
\end{abstract}

\section{Kata Kunci:}

Jihad, Agama, Ekonomi, Kiai dan Hukum islam

\begin{abstract}
:
This Article discusses how the real values of Islam can be poured into the business dynamics developed by Islamic Scholar (Kyai) as a guardian figure of Islam. The author tries to analyze the role of Madurese Kyai in developing Islamic economics, Islam as a religion can also have values and special spirit in developing public economics. Here is the importance of Kyai in Madura as the guard of Islamic values maintenance in all sectors, including in economics and business sectors. Spiritual values and Islamic business activities carried out by the Kyai can be seen as a form of jihad in economics, namely the establishment of the value of Shariah (Islamic law) in the
\end{abstract}


frame of economics and business applied and developed by the community)

\section{Keyword:}

Jihad, Religion, Economics, Kiai, and Islamic law

\section{Pendahuluan}

Kyai merupakan salah satu tokoh sentral yang berpengaruh di Madura. Mereka merupakan agent of social change. Dinamika yang terjadi pada kyai diyakini akan membentuk pemikiran masyarakat. Di sisi lain sebagai tokoh keIslaman tentunya memamahi betul ajaran Islam ${ }^{1}$. Sebagaimana dipahami ada tiga aspek ajaran Islam yaitu 'aqi>dah, shari>'ah dan akhla>q. Dalam konteks 'aqi>dah dan akhla>q sudah tertata dengan rapi dan mapan walaupun terjadi perdebatan mungkin dalam faksi yang furu>'iyah. Namun dalam ranah shariah khususnya mu'amalah terjadi sebuah fenomena yang menarik. Mutiara hikmah dari fiqh-fiqh baik yang klasik, modern maupun kontemporer yang dipahami hanya berhenti di untaian kertas tanpa makna, seperti mandul tanpa ada buah yang bisa diharapkan.

Islam sebagai agama yang menjadi spirit dari pergerakan elitnya telah menemukan kontestasinya dalam bidang ekonomi ${ }^{2}$ tidak seperti yang terjadi dalam Islamisasi dalam bidang hukum yang telah menjadi sebuah phobia Islam yang sulit untuk direalisasikan. Akan tetapi Islamisasi dalam ranah ekonomi mugkin akan bisa direalisasikan, namun dampak dibidang ekonomi ini tentunya tidak kalah dahsyatnya di banding dengan dampak Islamisasi di bidang hukum, karena ekonomi Islam $^{3}$ bisa dipahami sebagai salah satu jalur alternatif $^{4}$ dari kegagalan ekonomi konvensional.

\footnotetext{
${ }^{1}$ Islam sebagai agama merupakan salah satu alat untuk memahami fenomena dunia. Salah satu dari fenomena dunia adalah ekonomi. Sehingga konsep Islam mempunyai potensi untuk memahami bagaimana mengkaji ekonomi yang dijalankan oleh pemeluknya terutama kyai sebagai elit dalam agama Islam. Lihat Robert N. Bellah, Beyond Belief: Essays On Religion In A Post Traditionalism World (Berkeley lord Los angles: University of California, 1991), 146.

${ }^{2}$ Bahtiar Effendi, Masyarakat Agama Dan Pluralisme Keagamaan (Yogyakarta: Galang Press, 2001), 7.

${ }^{3}$ Bahkan wacana islamisasi dibidang ekonomi dimungkinkan telah menjadi melting pot antara kapitalis dengan kaum agamawan, walaupun dalam pertemuannya itu apakah seperti air dan minyak ataukah seperti gula dan kopi. Sebagai sebuah
} 
Agama dan ekonomi mempunyai sebuah relasi yang sudah dikaji oleh beberapa pakar dan peneliti. Teori yang cukup terkenal sebagai alat untuk menganalisis masalah ini adalah teorinya Max Weber yang terangkum dalam bukunya yang cukup terkenal yaitu The Protestant Ethics and Spirit of Capitalism. ${ }^{5}$

Tesis Weber tersebut membahas tentang relasi antara agama dengan ekonomi yang terbaca dalam etika Protestan dan semangat kapitalisme yang tumbuh. ${ }^{6}$ Weber mencoba mencari relasi antara penghayatan agama dengan pola prilaku ekonomi. Ia menambahkan kuatnya motivasi dalam perilaku ekonomi berakar kuat pada doktrindoktrin agamis, khususnya Protestan yang ia kaji. Bukti nyata yang empiris dari tesis ini sedikitnya ada dua, yaitu: pertama, order monastic, dimana ketika seseorang memiliki kehidupan yang saleh ternyata mempunyai reputasi dan prestasi yang gemilang dalam dunia materialisme. Kedua, beberapa sekte Protestan, terutama calvinis telah mempunyai prestasi yang gemilang dalam fase awal munculnya kapitalisme modern. ${ }^{7}$

Dengan demikian apakah relasi antara nilai dalam suatu agama atau dikenal dengan etika agamis akan mempunyai hubungan yang kausatif dengan aksi kapitalisme, atuakah hal itu, sebagaimana yang dinyatakan Weber merupakan sebuah kejadian yang bersifat hanya kebetulan saja, atau memang ternyata ada hubungan antara asketisme Protestan yang didominasi oleh sekte calvinis dengan semangat kapitalisme modern?. Pertumbuhan ekonomi yang terjadi di dunia modern terjadi dalam kurun waktu yang bersamaan dengan pergolakan keagamaan dalam agama Kristen yang dikenal dengan aliran Protestan. Sehingga pembaharuan dalam agama bisa dihubungkan dengan pembaharuan di bidang ekonomi. Semua yang

diskursus hal itu akan menjadi sebuah babak baru dalam perkembangan sebuh gagasan baik Islam maupun konvensional.

4 Sebagaimana ditegaskan oleh KH. Ma'ruf Amin yaitu "biarlah ekonomi Islam tumbuh bergandengan dengan ekonomi konvensional dan masyarakat yang akan menilainya".

${ }^{5}$ Lihat Max Weber, Etika Protestan Dan Spirit Kapitalisme, Terj. TW Utomo dan Yusuf Priya Sudiarja (Yogyakarta: Pustaka Pelajar, 2006), xxvii.

${ }^{6}$ Ajat Sudrajat, Etika Protestan dan Kapitalisme Barat; Relevansinya Dengan Islam Indonesia (Jakarta: Bumi aksara, 1994).

${ }^{7}$ Ibid., 4-5. 
ada di muka bumi merupakan anugerah Tuhan yang diberikan kepada para pemegannya sebagai tugas suci, sehingga mengejar keuntungan material berhubungan erat dengan konsep "panggilan" dari Tuhan dalam bidang keduniaan. Weber menyatakan bahwa konsep "panggilan" merupakan konsep agama yang ada setelah munculnya reformasi yang ditandai dengan munculnya Protestan yang belum ditemukan dalam agama Katolik dan zaman sebelumnya. Pengertian sederhana dari "panggilan" adalah urusan dunia yang biasa akan menjadi urusan agama. Lebih lanjut Luther menjelaskan bahwa panggilan adalah konsep agama tentang suatu tugas yang ditetapkan Tuhan, tugas hidup, suatu lapangan dimana seseorang harus bekerja. Dalam narasi lain panggilan adalah suatu cara hidup yang sesuai dengan kehendak Tuhan, dengan menjalankan tugas sesuai dengan kedudukannya di dunia. ${ }^{8}$

Fakta menyatakan bahwa reformasi Protestan yang dipelopori eleh calvinisme telah memberikan justifikasi kepada usaha-usaha yang dikembangakan oleh para kapitalis pada abad keenam belas dan tujuh belas. Nilai doktrinal agama dapat dipandang berfungsi ganda, yaitu sebagai sebuah relevansi agama dengan tantangan duniawi di satu sisi. Di sisi yang lain nilai doktrinal agama merupakan sebuah motivasi bagi perseorangan atau kelompok sebagai fungsionaris dari sebuah agama. ${ }^{9}$

Max Weber menyimpulkan bahwa semangat kapitalisme modern telah menjelma dari etika agama yang dikandung oleh agama Kristen Protestan dengan sebuah posisi yang terhormat dan menentukan kapitalisme. Hal itu merupakan sebuah pertautan yang harmonis antara nilai-nilai yang rasional dan irasional, antara ide, doktrin agama dan sebuah keharusan material, yang keduanya saling bertemu dan saling berkesesuaian. ${ }^{10}$

Penguatan dalam bidang ekonomi merupakan sebuah bentuk dakwah baru dalam kontes kekinian yang tentunya akan menjadi alternatif yang cukup berarti dalam konteks pembangunan kemanusiaan untuk menciptakan kehidupan yang lebih bermakna.

\footnotetext{
${ }^{8}$ Ibid., 6. Luther telah behasil meletakkan relasi berupa dukungan moral yang agamis terhadap prestasi kehidupan duniawi. Bekerja merupakan tugas suci bukan merupakan keharusan sebagaimana diyakini Katolik. Lihat Ajat, Etika..., 41-42.

${ }^{9}$ Ibid., 6-7.

${ }^{10}$ Ibid., 8 .
} 
Diakui atau tidak, dirasakan atau tidak, taraf kehidupan ekonomi umat tentunya akan mempengaruhi tingkat kehidupan sebuah umat bahkan menentukan martabat umat dalam kontestasi kehidupan ini, dimana sudah jamak diketahui bahwa umat Islam besar dalam kuantitas tapi lemah dalam kualitas terutama dalam kehidupan ekonomi. Prestasi dalam ranah ekonomi memang mudah di ukur karena konkret dalam kehidupan yang nyata. Hal itu tentunya tidak berdiri sendiri namun berdiri di atas sebuah mind set, dimana dinamika merupakan sebuah ketertarikan yang cukup layak untuk dikaji.

Pemahaman tentang ekonomi bisnis adalah aktivitas yang menggambarkan cara bisnis dan unit ekonomi dalam melaksanakan aktivitas ekonomi baik produksi, distribusi dan konsumsi dalam rangka mencapai dan memenuhi kebutuhan dan kesejahteraan rakyat. Sehinggga ekonomi bisnis merupakan sebuah aktivitas bisnis dalam skala yang lebih luas yang merupakan suatu hubungan yang saling mempengaruhi sebagai tolak ukur dari efektivitas dan efisiensi dari suatu masyarakat dalam usahanya ketika mencari kebutuhannya. ${ }^{11}$

Islam telah begitu menjadi bagian yang tidak terpisahkan dari masyarakat Madura. Agama telah menjadi sebuah ukuran yang bisa dikatakan sebagai sebuah barometer apa yang ia kerjakan sehari-hari. Bahkan orang Madura akan marah jika ia tersinggung soal agama. Mereka rela mati demi membela agama yang ia yakini yaitu Islam. Membela agama menurut orang Madura adalah shahid dan shahid merupakan sebuah lambang begitu terhormatnya seseorang yang menyandang gelar itu. ${ }^{12}$

Islam sebagai agama tidak dapat dipungkiri juga memiliki nilai-nilai atau spirit khusus dalam upaya mengembangkan ekonomi umat. Disinilah urgensi peran para kiai -sebagai pengawal tegaknya nilai-nilai Islam dalam segala sektor, termasuk sektor di ekonomi. Bagaimana keterlibatan para kiai dalam pengembangan ekonomi

${ }^{11}$ Pengertian ini menurut Nimpoena. Lihat Ismail Nawawi, Islam Dan Bisnis; Pendekatan Ekonomi dan Manajemen, Doktrin, Teori dan Praktik (Surabaya: vivpress, 2011), 3. Sedangkan arti sempit bisnis seperti sudah diterangkan di atas adalah sebuah perdagangan.

${ }^{12}$ Sunyoto Usman, Suku Madura Yang Pindah Ke Umbul Sari (Madura III) (Jakarta: Proyek Peningkatan Sarana Pendidikan Tinggi DEPDIKBUD, 1979), 374. 
umat berdasarkan pakem atau aturan-aturan islam (hukum islam), penulis mencoba mengulasnya dalam artikel ini.

\section{Keterlibatan kiai di Madura dalam berbisnis berbasis syari'ah}

Kyai sebagai pimpinan tradisional tentunyai mempunyai kharisma. Artinya jika ada keinginan dari kyai untuk membina ekonomi umat akan lebih mudah terealisir karena kyai sebenarnya adalah dinamisator ${ }^{13}$ sehingga kyai mampu menjadi cultural broker bahkan mampu menjadi power broker ${ }^{14}$ di sebuah entitas kultur kasyarakat. Dakwah kyai dengan membangun fondasi ekonomi umat sama seperti membina fondasi tauhid yang akan menyelamatkan umat dari kekafiran sebagai salah satu akibat dari kefakiran yang dideritanya. Kehidupan yang berkualitas dalam segi kebahagiaan merupakan sebuah cita-cita bersama dalam kerangka pembangunan kehidupan yang ada dan menjadi cita-cita bersama umat Islam. ${ }^{15}$

Kyai selama ini hanya identik dengan pemimpin agama namun sebenarnya kyai adalah uswah hasanah bagi umatnya sebagaimana para nabi, dimana kyai adalah pewaris nabi sehingga harus mampu memainkan peran itu. Namun kenyataannya banyak hal yang ironi di Madura, perekonomian kyai begitu maju namun kehidupan ekonomi umat tetap. Sebenarnya ketika kyai merupakan panutan maka kehidupan ekonomi umat harus selaras dan seimbang serta bisa mengikuti langgam berpikirnya kyai sehinggga gap diantara mereka yang terjadi tidak begitu menganga dengan lebar sekali.

Kyai bukan hanya "menguasai" pesantrennya melainkan juga merambah ke desa-desa. Seluruh problematika kehidupan masyarakat meminta penyelesaian kepada seorang kyai. Kyai tidak terasa telah menjadi tolak ukur kehidupan masyarakat. Seluruh sendi

\footnotetext{
${ }^{13}$ Dinamisator dipahami sebagai sebuah pihak yang mampu memahami sesuatu yang bersifat kompleks dan rumit kemudian hal itu dicerna sehingga mudah untuk dipahami pihak lain. Dalam hal ini tentunya ada sebuah filter (penyaringan).

${ }^{14}$ Istilah ini diperkenalkan oleh Cliffort Gertz. Bandingkan dengan Kuntowijoyo. "Social Change in an Agriculture Society: Madura 1850-1940". Disertasi, Universitas Columbia New York. Terj. M. Effendi dan P. Amaripuja, Perubahan Sosial dalam Masyarakat Agraris. Madura 1850-1940. (Yogyakarta: Matabangsa, 2002), 593.

${ }^{15}$ Sebagaimna selalu termaktub dalam doanya: fi al-dunyā hasanah wa fi al-akhirat hasanah wa qinā 'adāb al-nār. sebuah dambaan dan cita-cita agar mempunyai kehidupan yang bahagia di dunia dan akhirat.
} 
kehidupan masyarakat memerlukan jasa seorang kyai. Mulai dari proses menikah, melahirkan, aqiqah, sampai meninggal dunia tidak terlepas dari peran kyai. Tentunya kyai juga akan berpengaruh terhadap kehidupan sosial ekonomi masyarakat Madura. ${ }^{16}$

Fanatisme agama merupakan salah satu ciri orang Madura. Disamping itu etos kerja yang tinggi, gemar berpetualang, mandiri dan mempunyai semangat berusaha yang tinggi. Hal itu merupakan potensi ekonomi yang cukup tinggi yang dimiliki kaum Madura. 17 Sebagai orang yang gemar bermigrasi maka kaum Madura dikatakan mempunyai kesamaan dengan suku Minang bahkan dengan etnis yang kental dengan urusan bisnis yaitu Cina. Ketiga etnis itu yaitu Minang, Cina dan Madura dianggap suka migrasi dan ulet, sehingga dimanapun bisa dijumpai masakan Padang, dimanapun juga bisa dijumpai orang Madura. ${ }^{18}$ Bahkan mereka biasanya lebih menyukai bisnis di sektor informal seperti penjual sate, masakan Padang, toko klontongan, dan lain sebagainya.

Kaum Madura tidak bisa dipisahkan dengan kyai. Hal itu tentunya akan melahirkan fanatisme agama, gejala itu bisa dilihat dari bagaimana kedekatan orang Madura dengan pimpinan informalnya yang disebut dengan kyai. Status kyai akan mempunyai kharisma yang cukup tinggi dikalangan masyarakat Madura bahkan melebihi posisi informal sekalipun. Apalagi seorang kyai yang menjadi pemangku pesantren besar di Madura dan kealimannya sudah diketahui. ${ }^{19}$

Progresifitas pemikiran ekonomi kyai Madura tentunya akan menjadi sebuah madhhab berpikir yang bisa dikaji untuk menambah khazanah keilmuan apalagi dalam konteks ekonomi Islam yang sedang tumbuh dengan begitu suburnya. Warna dan polesan ciri khas serta kearifan lokal yang dikandung orang Madura akan memberikan sentuhan yang dimungkinkan akan menggerakkan dinamika

\footnotetext{
${ }^{16}$ Abd. Halim Soebahar dan Hadanah Utsman, Hak Reproduksi Perempuan Dalam Pandangan Kiai (Yogyakarta: Pusat penelitian kependudukan UGM , 1999), 18-19.

${ }^{17}$ Bachtiar effendi, “ Pertumbuhan Etos Kerja Kewirausahaan Dan Etika Bisnis Di Kalangan Muslim:, dalam Effendi, Maysrakat., 195-219.

${ }^{18}$ David CL ching, Sukses Cina Perantauan, ed. Rahayu Ratna Ningsih dan Budi Kurniawan, (Jakarta: tajidu press, 2002), 94-115.

${ }_{19}$ Iik Arifin Mansurnoor, Islam in an Indonesian World Ulama of Madura (Yogyakarta: Gajah Mada University Press, 1990), 4.
} 
pemikiran ekonomi dalam konteks keindonesiaan. Agama bagi orang Madura merupakan suatu hal yang sangat pokok dan mendasar. Ia akan sangat tersinggung ketika persoalan agama disinggung. Tentunya menarik apabila dikorek dalam sisi pemikiran ekonomi Islamnya.

Di Madura, kedua organisasi keagamaan seperti NU dan SI tumbuh dengan subur. Oleh karenanya amat wajar bila beberapa kiai yang memimpim pondok pesantren di Madura ikut terjun ke dunia bisnis. Tentunya bisnis yang yang dikembangkan adalah bisnis yang tidak menyimpang dari prinsip-prinsip ajaran islam, baik menyangkut bidang bisnis yang digelutinya maupun tata cara menjalankanya.

Penulis sempat mewawancarai beberapa orang kiai yang ada Madura, tentang bagaimana pandangan mereka tentang dunia bisnis yang dijalankannnya. Berikut penulis uraikan beberapa pandangan beliau yang secara garis besar sebenarnya nilai spiritual ekonomi yang diungkap para beliau itu bersumber dari landasan spiritual alqur'an dan al-hadits.

a. Pandangan KH. Muhammad Syamsul Arifin ${ }^{20}$

Menurut KH. Muhammad Syamsul Arifin landasan dalam berbisnis bisa dipahami dari ayat Al Qur'an yang berbunyi :

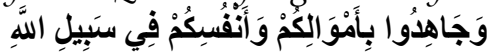

Dari potongan ayat di atas maka jihad dibedakan kepada lima macam jihad yaitu: pertama, jihad ma>li> (harta), kedua, jihad $t a^{\prime} l i>m i>$ (pendidikan), ketiga, jihad siya>si> (politik), keempat, jihad qita $>l i>$ (perang) dan kelima jihad nafs (jiwa). Dengan demikian berjuang dalam bisnis termasuk jihad ma>li>.

Menurut KH. Muhammad Syamsul Arifin Al Qur'an diyakini telah memberi petunjuk terkait dengan bisnis. Namun dalam praktiknya ia mau belajar kepada siapa saja dengan sebuah prinsip ambillah hikmah itu walaupun dari seekor keledai. Sehingga dalam menajamkan pengetahun bisnisnya ia mau belajar walaupun kepada Cina sekalipun.

Sedangkan salah satu hadith Nabi yang mendukung ayat di atas adalah Suatu saat ketika Nabi sedang menghitung harta rampasan perang di masjid maka datang seorang pemuda yang

${ }^{20}$ KHMSA, Wawancara, Pamekasan, 24 Juli 2016. 
gagah perkasa namun ia tidak ikut berperang. Para sahabat yang lain menyayangkan kelakukan sahabat yang gagah perkasa tersebut karena tidak ikut berperang. Kemudian Nabi bersabda mungkin pemuda ini mempunyai orang tua yang harus dijaga dan dinafkahi atau ia bekerja agar tidak meminta-minta, maka jika demikian maka ia sebenarnya telah berjuang di jalan Allah $(f i>$ sabi $>l$ alla $>h)$.

b. Pandangan KH. Misbahul Munir Asy'ari'21

Ia menegaskan bahwa ia aktif di dunia bisnis karena ingin mengamalkan hadith yang berbunyi: عمل الرجل بيده

Para sahabat di masa dulu banyak yang berbisnis dan keuntungan dari bisnis demi perjuangan Islam. Di samping itu untuk menguatkan batin maka santri diwajibkan sholat $\mathrm{d}$ \}uha> dan sholat tah\}ajju>d. Serta membaca surat al-wa>qi'ah. Dalam doa bersama dijelaskan untuk mendoakan ekonomi pesantren. Alhamdulillah $\mathrm{KH}$. Misbahul Munir Asy'ari (KHMA) menegaskan ternyata memang ada dampaknya terhadap swalayan di pesantren dimana omsetnya sekarang sudah di atas 1 Miliyar.

Kyai Asy'ari sebagai perintis pesantren Kebun Baru bukan hanya dikenal sebagai ulama yang alim namun ia dikenal sebagai peletak batu pertama dan penggagas toko sebagai bisnis di PCNU Pamekasan. Dengan toko rintisan K Asy'ari telah menjadi tulang punggung ekonomi PCNU Pamekasan sampai sekarang, bahkan K Asy'ari menghibahkan tanah yang di dalamnya ada sarang walet kepada PCNU Pamekasan.

c. KH.Muhammad Hasan 22

Grand konsep KH.Muhammad Hasan (KHMH) disandarkan pada ayat yang berbunyi :

Menurut KHMH semua urusan termasuk urusan bisnis semuanya disandarkan pada ayat tersebut. Semua aktivitas harus dirujukkan ke sana. Dari Allah kita berasal dan kepada Allah kita akan kembali. Kalau kita berjiwa futuristic maka ending-nya hanyalah kepada Allah sehinggga kita harus siap menghadap Allah.

${ }^{21}$ KHMA, Wawancara, Pamekasan, 20 Agustus 2016.

${ }^{22}$ KHMH, Wawancara, Pamekasan, 25 Agustus 2016. 
Dari konsep tersebut banyak turunannya di antaranya ia menegaskan perlunya ridla dari orang tua dan ending-nya hanyalah ridla Allah yang diharapkan. Dengan demikian maka dimungkinkan manusia tidak lupa, walaupun bisa diyakini manusia adalah tempat salah dan lupa.

Oleh karena itu sering ia bertanya kepada abahnya ketika BBM naik, maka orang tuan KHMH hanya berkomentar:

“..BBM naik, gak masalah BBM ini naik, namun doakan walaupun naik kita mampu beli, semahal apapun kalau kita kuat beli gak masalah, sebaliknya semurah apapun kalau kita tidak mampu beli, itu omong kosong. Ini konsep sederhana namun maknanya lebar. Orang hidup itu tugasnya minta, yang penting tekka hajat. haji tiap tahun, mobil ganti tiap tahun kan itu itu tekka hajat (tercapai cita-citanya)."23

Dalam menjalani hidup termasuk bisnis hanyalah untuk memenuhi kewajiban dengan niat ibadah. Jika terjadi masalah maka dikembalikan kepada Allah SWT karena kepada-Nya kita akan kembali. Sedangkan lelakon spiritual cukup istikharah saja. Untuk mengikat secara emosional dengan para pekerja maka biasanya diadakan pembacaan surat yasin tiap malam jumatan. Di samping itu walaupun dimasa yang sudah canggih ini maka ia masih menggunakan radio orari. Hal yang dipentingkan dalam ini adalah bagaimana semua karyawan dan $\mathrm{KHMH}$ satu kalimat. Ia yakin ada perbedaan antara orang yang bekerja hanya bekerja saja dengan bekerja tapi mempunyai hubungan emosional dengan pimpinannya.

Ia tidak segan-segan turun ke bawah dan silaturrahim kepada para karyawannya. Ia selalu meyarankan agar yang satu membantu yang lain jika ada masalah, misalnya mobilnya mogok dan lain sebagainya termasuk jika ada masalah pribadi. Ia terinspirasi bagaimana eratnya hubungan antara pekerja dengan majikan di toko tuan arab, ketika ada satu pembeli yang komplain tehadap tuan arab itu. Tuan arab tersebut hanya diam, tetapi pekerja yang lain secara spontan membela tuan arab itu. Ikatan hati itu bukan hanya di rupiah tapi ikatan hati lebih mahal dari segalanya. Pada zaman sekarang mencari pekerja yang profesional mungkin banyak namum mencari pekerja yang bekerja dengan hati dan mempunyai ikatan hati agak sulit. Sehingga ia selalu mengingatkan kepada karyawannya bahwa

${ }^{23}$ KHMH, Wawancara, Pamekasan, 25 Agustus 2016. 
mereka merupakan insan pesantren sehingga harus menjaga segala tingkah laku dalam muamalah dengan manusia. Memang $\mathrm{KHMH}$ menegaskan konsep kekeluargaan sengaja diciptakan dalam lingkungan kerja sehingga mereka mempunyai sikap yang lunak termasuk kepada pelanggan dan sesama pekerjanya. Semua hal harus dibicarakan dan dicarikan solusinya jika terjadi sebuah masalah.

Ia juga menegaskan bahwa pekerjaan ini hanyalah media untuk memenuhi kewajiban. Memang sebagai kepala keluarga harus mencai nafkah, namun Islam tidak pernah mengatur tentang jumlahnya. Jika hanya mampu menyangkul satu saja maka sudah cukup. Sesuatu yang penting adalah keseimbangan antara tawakkal dengan ikhtiyarnya. Jika tawakkalnya besar maka tidak masalah ihktiyarnya kecil, demikian juga sebalikanya, kalau tawakkalnya kecil maka ikhtiyarnya harus dibesarkan atau diperbesar sehingga balance antara tawakkal dengan ikhtiyar. Jika balance ia meyakini semuanya akan mengalir dalam hidup ini dengan baik.

Kalau ditelisik lebih jauh sebenarnya KHMH merupakan cicit dari Kyai Majid sebagai pengasuh Banyuanyar sekaligus perintis pesantren Bata-Bata. K Majid merupakan sosok yang disegani kealimannya, namun bukan hanya dalam bidang ilmu agama, akan tetapi ia juga merupakan seorang bussnisman yang handal. Artefak rintisan bisnis K Majid bisa disaksikan sampai hari ini yaitu bisnis di sekitar kawasan terminal Bugih bahkan sampai ke Pasar Tujuh Belas Agustus. Memang sudah banyak yang berpindah ke pihak lain, namun masih banyak yang masih menjadi lahan bisnis keturunan $\mathrm{K}$ Majid.

Menurut penuturan KHMH sebagai berikut :

“...Konsep bisnis K Majid di Bugih. Di timur jalan itu ada warung, warungnya di jauhkan dari jalan sehingga ada pohon yang bisa tumbuh dan enak untuk tempat parkir bagi yang mau berbelanja di warung itu. ini merupakan terobosan dalam bisnis yang luar biasa instingnya. Tiap hari selasa K Majid "morok" di Masjid Andil, beliau bawa gula kopi untuk disetorkan ke warung, pulangnya beliau nagih sendiri. Buka toko Sawah yang betul-betul mempraktikkan syariah. Beliau tokoh yang memegang syar'i. Beliau berprinsip hukum itu jangan ambil yang ringan, kalau ambil yang berat seandainya tergelincir masih ada hukum yang ringan. $K$ majid Pernah beli es di toko Sudi Mampir kemudian ditertawakan oleh 
tukang becak karena membeli es dengan menawar lebih dulu, cek saranah melle es nabar (keterlaluan, belie es saja masih menawar). Kemudian beliau menegaskan inilah (konsep tawar) adalah prinsip syariah, kalau uang, ini saya punya satu kantong. Yang kanan terima barang yang kiri bayar. (yad bi yad). Beliau hati-hati dan detail tentang syariah." 24

Sebagai tokoh agama $\mathrm{K}$ Majid tidak segan-segan untuk berbisnis sehingga darah bisnis dan darah ulama memang menetes di pesantren Bata-Bata dan Banyuanyar, sehingga semangat keagamaan melaui pesantren dan semangat bisnis yang dikelola dengan sungguh-sungguh merupakan sebuah fenomena yang bisa ditarik akar historisnya.

Menut penulis, nilai spiritual bisnis yang diimplementasikan oleh bersandar pada teks Al Qur'an dan al Hadith. Pertama, bisnis di anggap sebagai jihad ma>li>. Hal itu disandarkan pada Al Qur'an surat al Taubah ayat 41:

"Berjihadlah dengan harta dan dirimu di jalan Allah"25

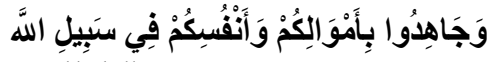

Dari ayat ini menurut KHMSA dapat dipetakan bahwa jihad ada lima jenis yaitu jihad $\left.m a\rangle|i\rangle, t a^{\prime}|i\rangle m i\right\rangle$, siya $>$ si $\rangle$, qita $>\mid i>$ dan nafs.

Untuk menguraikan lebih luas tentang jihad dan bisnis maka diperlukan sebuah pendukung konsep jihad yang dicetuskan oleh salah satu pemikir muslim yaitu Yusuf Qardlawi. Ia menjelaskan bahwa definisi jihad adalah: "jihad secara etimologi berarti mencurahkan usaha, kemampuan dan tenaga. Jihad juga berarti menanggung kesulitan." 26

Secara istilah kata jihad lebih diorientasikan dalam arti peperangan untuk menolong agama dan membela kehormatan umat. Ada 34 kali penyebutan kata jihad dalam Al Qur'an. Namun dalam

${ }^{24}$ KHMH, Wawancara, Pamekasan, 25 Agustus 2016.

25 DEPAG, Al Qur'an..., 285. Lihat juga Rizky Andriati, Nurul Huda, "The Influences of productive Zakah Mentoring to the Saving Behavior and The Prosperity of Poor Housewife" Al-IQTISHAD: Jurnal Ilmu Ekonomi Syariah (Journal of Islamic Economics), Volume VII nomor 2 (juli 2015), 241.

${ }^{26}$ Yusuf Qardhawi, Fiqh Jihad: Sebuha Karya Monumental Terlengkap Tentang Jihad Menurut Al Qur'an dan Sunnah, terj, Irfan Maulana Hakim dkk (Bandung: Mizan Pustaka, 2010), lxxv. 
kitab $z a>d$ al-ma'a>d tulisan Ibn al-Qayyim, telah membagi jihad kedalam tiga belas tingkatan yang dikenal dengan istilah al- jiha $>d$ almada>ni>. ${ }^{27}$

Jihad dalam konteks ekonomi telah disinggung sebenarnya oleh Ibn Al- Qayyim dalam pemetaanya yang dikenal dengan aljiha $>d$ al-mada>ni> (jihad sipil). Inti dari jihad sipil adalah sebuah usaha yang sungguh-sungguh untuk memenuhi berbagai problematika masyarakat dan menututpi tuntutan moral dan materiilnya serta membangkitkan dalam segala lini sehingga umat bisa meraih posisinya yang berdaya dan terhormat. ${ }^{28}$

Jihad ekonomi dipahami sebagai usaha yang sungguhsungguh untuk mengais rizki dengan penuh semangat dan kerja keras serta menikmati karunia Allah yang telah dianugerahkan kepada hambanya. Diriwayatkan dari Ka'ab ibn 'Ujrah bahwa pada suatu hari Rasulullah duduk bersama para sahabatnya. Kemudian ada seorang laki-laki dengan penuh semangat dan keuletan. Kemudian para sahabat menyatakan: seandainya ini termasuk jihad $f i$ $>$ sabi $>$ l alla $>h$.

Dalam sebuah hadits Nabi pernah bersabda :

“....... Jika dia keluar untuk bekerja untuk (keperluan) anaknya yang masih kecil berarti ia berada di jalan Allah. Jika ia keluar untuk bekerja untuk orang tuanya yang sudah tua renta berarti ia berada di jalan Allah. Jika ia keluar untuk menjaga kesucian dirinya (dari meminta-minta) berarti ia berada di jalan Allah. Dan jika ia keluar untuk pamer dan menyombongkan diri berarti ia berada di jalan setan..$^{29}$

Pembeda bobot dan nilai dari suatu pekerjaan dalam perspektif syari'ah adalah ternyata terletak pada niatnya. Jika ia berniat dengan niat yag sesuai dengan niat yang dibenarkan shariah maka ia berada di jalan Allah, namun jika ia berniat tidak sesuai dengan tuntunan shariah maka ia jauh dari Allah dan berada di jalur yang justru dilaknat oleh Allah yaitu jalan setan.

\footnotetext{
${ }^{27}$ Ibid., Fiqh, lxxv.

${ }^{28}$ Ibid., Fiqh, 148-149.

${ }^{29}$ HR Al-T \}abrani dalam kitab al-s $\} a w i>r$, juz 2,. 248. Bandingkan dengan al$k a b i>r$ juz 19, 129.
} 
Jika aktivitas bisnis diniati untuk memenuhi ekonomi yang sesuai dengan shariah baik keluarga, dirnya sendiri dan masyarakat maka hal itu termasuk sebuah jihad fi> sabi $>l$ alla $>h$. Akan tetapi jika aktivitas bisnis yang dijalankan dengan sunguh-sungguh tetapi untuk menyombongkan diri sendiri dan berfoya-foya maka ia sudah keluar dari jihad $f i>$ sabi $>l$ alla $>h$. bahkan ia telah melaju di sabi $>l$ al-shait $\} a>n$.

Sudah sangat jelas bahwa semangat dari jihad ekonomi merupakan sebuah usaha yang bisa meningkatkan dan memberdayakan perekonomian umat, dengan melakukan segala aktivitas baik yang berhubungan dengan ekonomi dan bisnis maka sesungguhnya ia berada dalam jihad $f i>$ sabi $>l$ alla $>h$.

Apalagi jika seseorang seperti yang diimplementasikan kiai membuka peluang bisnis untuk mengurangi permasalahan keumatan seperti pengangguran meruapakan sebuah jihad di bidang ekonomi. Paradigma menciptakan pekerjaan harus dimulai oleh pihak yang dekat dengan nilai-nilai agama baik itu kyai, santri dan alumni serta masyarakat simpatisan pesantren sehingga akan melahirkan sebuah mileu yang akan menumbuhkembangkan jihad ekonomi dalam umat. Hal itu bisa membuang jauh-jauh paradigma selama ini bahwa bisnis hanyalah urusan mereka yang tidak paham agama dan anggapan bahwa kyai tidak atau haram berbisnis. Dengan demikian bisnis bukan hanya urusan dunia dengan mengejar keuntungan namun juga proyek akhirat bahkan bobotnya bisa disejajarkan dengan jihad.

Itulah sebenarnya lisa>n al-ha>l dan $d a^{\prime} w a h$ bi al-ha>l dari seorag kyai sebagai leader bagi umatnya. Kalau kyai mempunyai semangat jihad ekonomi maka mudah sebenarnya memobilisasi umatnya, karena kyai sebenarnya adalah penjaga nilai-nilai shariah utamanya dalam masalah ekonomi.

Kalau hal ini digaris bawahi maka akan mempunyai kekuatan yang tidak bisa dianggap sebelah mata. Dengan demikian maka posisi umat yang selama ini lemah akan mempunyai bargainning yang bisa dinaikkan. Setelah ditelisisk lebih dalam sebenarnya karena faktor lemahnya ekonomi umat Islam sehingga kaum muslimin mempunyai bargainning yang lemah. Tentunya bayak faktor yang mempengaruhi posisi umat Islam pada era kontemporer ini. Namun dengan maksud tanpa ingin mengenyampingkan faktor lain seperti politik dan hukum maka faktor ekonomi mempunyai penyebab yang signifikan. Apapun istilahnya (meminjam komentar $\mathrm{KHMH}$ ) penguatan dibidang 
ekonomi itu dipentingkan, bukan hanya ibadah (meminjam komentar KHMA) tetapi berusaha dalam ranah bisnis merupkan sebuah jihad (meminjam istilah KHMSA).

Jihad ekonomi tentu akan menjadi tawaran dan proyek yang perlu dikawal karena betapa akut, kronis dan beratnya masalah keumatan khususnya di bidang ekonomi. Kalau tidak dengan istilah jihad maka dimungkinkan tidak akan ada gerakan yang bersifat "revolusi" dari umat Islam, sehingga posisi umat yang besar secara kuantitas namun miskin secara kualitas dan kapasitas khususnya dalam bidang ekonomi.

Ekonomi merupakan kunci truf untuk masuk ke dalam peningkatan faktor yang lain. Jika ekonomi seseorang meningkat maka tingkat pendidikan, kesehatan dan taraf hidupnya akan meningkat dengan sendirinya. Kalau meminjam pemetaan istilah fard\} ' 'ayn dan kifa>yah maka ekonomi sebenarnya berada pada posisi fard\} $u$ 'ayn, sehingga menjadi kewajiban setiap jiwa yang bernyawa untuk berjihad dalam bidang ekonomi.

Dasar ajaran Islam yang bersumber dari Al Qur'an dan Al Hadith sudah sangat jelas memberikan referensi sejarah betapa pentingnya perjuangan di bidang ekonomi, dalam istilah Nabi memelihara kesucian dirinya dari meminta-minta(atau keinginan meminta-minta) ${ }^{30}$ maka posisi 'iffah' ${ }^{31}$ yang ditawarkan kyai akan menjadi terminal yang akan memperjelas bahwa jihad ekonomi kyai dalam berbisnis bukan untuk ajang menyombongkan diri, pamer dan kufur terhadap nikmat, melainkan untuk menjadi pelindung dari godaan dari dalam dirinya berupa keinginan dan meminta-minta kepada pihak lain serta melindungi muru>'ah kyai di mata orang lain. Hal itu sesuai dengan Pernyataan Al-Ghazali yang menyatakan bahwa niat yang dianjurkan dalam berbisnis adalah untuk menjauhkan diri dari pekerjaan dan keinginan meminta-minta kepada orang lain (al-isti'fa>f), 32

\footnotetext{
${ }^{30}$ Dalam istilah Al Qur'an dikenal ada istilah sāil dan maḥrūm, yaitu orang miskin yang berhak terhadap zakat baik di meminta (sāil ) atau ia tidak meminta (mahrūm,).

31 Al-Ghazali, Ihyā' 'Ulūm al-Dīn, Juz II. (Mesir: Maktabah Nahḍah,1964), 84.

${ }^{32}$ Ibid. Lihat juga Abdul Maji, Sabri dan Zulhanizar, Said. " The Patronage Behavior of Islamic Bank's Customers : Imperical Studies in Aceh”, Al-IQTISHAD: Jurnal
} 
Agama yang bisa dilihat dalam aktivitas tohohnya dalam pandangan Weber mempunyai posisi yang determinan terhadap kehidupan seseorang. Hal itu terjadi pada kyai. Agama telah menjadi urat nadi kyai. Pesantren didirikan salah satu untuk tujuan utamanya adalah untuk membentengi agama, bahkan pesantren dikenal sebagai lembaga yang menjadi benteng untuk mendidik seseorang menjadi penganut agama yang berkualitas. Semua lini kehidupan kyai harus sesuai dengan prinsip-prinsip shariah, termasuk kegiatan bisnisnya. Sudah jelas bahwa kegiatan bisnis kyai didasari oleh landasan spiritual yang bersumber dari Shariah.

Dalam pandangan yang lain Weber melihat bahwa agama dengan ekonomi mempunyai hubungan yang kausatif. Artinya agama mempunyai pengaruh terhadap ekonomi seseorang, namun masih ada faktor lain yang mempengaruhi kehidupan ekonomi seseorang. Hal itu bisa dilihat pada penelitian Muhtadi di Malang terhadap pengrajin tempe. Dalam kontek kyai di Madura, juga terjadi hal yang sama. Akan tetapi bukan dipengaruhi oleh tingkat pemahaman keagamaan namun pemahaman keagamaan dari kyai telah melahirkan sebuah pandangan bahwa bisnis itu hanyalah ikhtiyar, bukan tujuan akhir. Sehingga walaupun ada faktor lain selain agama namun agama tetap menjadi faktor yang dominan bagi kyai yang mempengaruhi kehidupan bisnisnya.

Etika Protestan dari Weber juga menyatakan bahwa prestasi seseorang di dunia itu melambangkan "pilihan" Tuhan kepada seseorang. Artinya orang yang berprestasi dalam kehidupan materinya berarti ia merupakan pilihan Tuhan. Inilah perbedaan yang sangat signifikan dengan pandangan kyai. hal itu disebabkan oleh perbedaan antara Islam sebagai agama dari kyai dengan Protestan sebagai sebuah agama yang dijadikan kajian dalam tesis Weber. Dalam pandangan Islam sebagaimana diyakini bahwa prestasi dalam kehidupan dunia berupa kesuksesan bisnis misalnya bukan merupakan jaminan posisi seseorang di sisi Tuhan. Akan tetapi yang menjadi jaminan kemuliaan seseorang di sisi Allah SWT hanyalah tingkat ketakwaanya kepada Allah SWT.

Ilmu Ekonomi Syariah (Journal of Islamic Economics), Volume VIII nomor 2 (Juliu, 2016), 201. 
Djakfar setelah menggunakan teori dasar dari Weber berhasil memetakan tipologi dialektika etika pada pedagang buah di Malang. Salah satu dari kelompok pedagang adalah adanya pedagang yang masuk ke dalam kelompok jujur yang meyakini bahwa bisnis itu adalah ibadah sehingga harus mematuhi etika yang bersumber dari nilai-nilai agama yang diyakininya yaitu Islam. Sedangkan kyai di Madura juga meyakini bahwa menjalankan bisnis itu adalah ibadah. Namun kyai meyakini bisnis bukan hanya ibadah melainkan jihad. Dengan demikian bisnis harus dijalankan dengan konsep jihad, yaitu berjuang dengan sungguh-sungguh dengan segenap hati serta mengeluarkan semua kompetensi yang terbaik. Tujuan akhirnya adalah rid\}a> dari Allah SWT sebagai konsekwensi dari niat menjalankan bisnis sebagai sebuah perjuangan $f i>$ sabi $>l$ alla $>h$.

\section{Penutup}

Nilai spiritual dari aktivitas bisnis yang dilakukan oleh para kiai adalah jihad di bidang ekonomi (jihad ma>li/iqtishad $>$ ), 'iffah dan $d a^{\prime} w a h$ bi al-h\}a>l. Pemahaman terhadap agama yang mengkristal dalam jiwa kiai telah menjadi sebuah panduan yang jelas bagaimana ia melakukan aktivitas perekonomiannya. Dalam ranah tersebut jelas terlihat bagaimana relasi ekonomi dan agama dalam aktivitas perekonomian kiai. Gerakan pemikiran keagamaan akan terekam dalam gerakan perekonomiannya. Manifestasi perekonomian kiai adalah bentuk kongkret relasi agama dan ekonomi yang bertemu dalam aktivitas ekonomi yang digerakkan oleh kiai. Semua lini kehidupan kiai harus sesuai dengan prinsip-prinsip syari'ah, termasuk kegiatan bisnisnya. Sudah jelas bahwa kegiatan bisnis kiai madura didasari oleh landasan spiritual yang bersumber dari syari'ah. Nilainilai Islam yang termaktub dalam hukum yang dikenal dengan syariah telah menjadi spirit dan inspirasi pengembangan ekonomi di Madura, sehingga nilai-nilai Islam yang terkandung dalam hukum Islam telah menjadi spirit dan inspirasi pengembangan ekonomi di Madura.

\section{Daftar Pustaka}

Abdul Maji, Sabri dan Zulhanizar, Said. " The Patronage Behavior of Islamic Bank's Customers : Imperical Studies in Aceh". Al- 
IQTISHAD: Jurnal Ilmu Ekonomi Syariah (Journal of Islamic Economics), Volume VIII nomor 2 (Juliu 2016).

al-Ghaza>li >, Abu> H\}a>mid bin Muh\}ammad. Ihya>' 'Ulu>m alDi>n, Juz II. Mesir: Maktabah Nahd\}ah,1964.

Al-Haritsi, Jaribah bin Ahmad. Fikih Ekonomi Umar Bin Al-Khatthab, terj. Asmuni Solihan Zamakhsyari. Jakarta: Pystaka AlKautsar, 2014.

Ali Rama, Ali. “Analisis Kesesuaian Konstitusi Ekonomi Indonesia terhadap Ekonomi Islam". Al-IQTISHAD: Jurnal Ilmu Ekonomi Syariah (Journal of Islamic Economics), Volume VI nomor 1 (Januari 2014)

Al-Zuhayli, Wahbah. al-Figh al-Islami wa Adillatuh. Beirut: Dar al-Fikr, 1989.

Andriati, Rizky dan Huda, Nurul. “The Influences of productive Zakah Mentoring to the Saving Behavior and The Prosperity of Poor Housewife" Al-IQTISHAD: Jurnal Ilmu Ekonomi Syariah (Journal of Islamic Economics), Volume VII nomor 2 (juli 2015).

DEPAG. Al Qur'an dan Terjemahnya. Surabaya: Jaya Sakti, 1971.

Fealy, Greg. dan Greg Barton (ed), Tradisionalisme Radikal: Persinggungan NU- Negara. Yogyakarta: LKiS, 1997.

Haekal, Muhammad Husein. Umar Bin Khattab, terj. Ali Audah. Bogor: Litera Antar Nusa, 2013.

Hasan, Zainul, dkk. NU Dalam Lintasan Sejarah, Meneropong Perjalanan NU di Pamekasan. Pamekasan : PCNU Pamekasan, 2006.

Huda, Nurul. Sekilas Nahdlatut Tujjar. Surabaya: Pustaka Pesantren , 2004.

Huda, Nurul, dkk. "The Development of Human Resources In Islamic Financial Industries From economic and Isalmic financial graduates". Al-IQTISHAD: Jurnal Ilmu Ekonomi Syariah (Journal of Islamic Economics), Volume VIII nomor 1 Januari 2016.

MM, Billah, "Pergolakan Nu dan Kelompok Islam; Interplay dalam gerakan tandingan dengan gerakan tandingan dan tandingan atas gerakan tandingan" Jurnal Tasywirul Afkar, Edisi No. 21998.

Nawawi, Al Fath Al Bari. Beirut: dar Al fikr, tt. 
Nawawi, Ismail. Isu-Isu Ekonomi Islam; Kompilasi Pemikiran Dan Teori Menuju Praktik di Tengah Arus Ekonomi Global, Buku 2. Surabaya: Viv Press, 2013.

Sobary, Muhammad. Kesalehan Dan Tingkah Laku Ekonomi. Yogyakarta: Yayasan Bentang Budaya, 1995.

Weber, Max, Etika Protestan Dan Spirit Kapitalisme, Terj. TW Utomo dan Yusuf Priya Sudiarja, Yogyakarta: Pustaka Pelajar, 2006.

Yusuf, Burhanuddin. "Human Resources Development of Shari'iah Banking: Phenomenological Approach". Al-IQTISHAD: Jurnal Ilmu Ekonomi Syariah (Journal of Islamic Economics), Volume VII nomor 2 (Juli 2015). 